\title{
A Study of the English Translations of the Qur'anic Verb Phrase: The Derivatives of the Triliteral
}

\author{
Mehdi F. al-Ghazalli \\ Translation Department, Faculty of Arts, AlMustansiriyia University, Iraq \\ Email: mehdi_falih2000@yahoo.com
}

\begin{abstract}
The present study is concerned with throwing light on the accuracy of the English translations of the Arabic triliteral verb derivatives as found in Qur'ãnic ayahs. The triliteral can be affixated with one radical, two radicals or three radicals to obtain such derivatives that have senses distinct from the base forms. This holds true of the derivatives of the quadrilateral. It is hypothesized that the English translations of such ayahs seem mainly inaccurate to convey the same senses from the source text into the target text. To validate this, ayahs containing such derivatives have been randomly chosen, and their renderings have been assessed. It has been found out that the senses of the derivatives of the triliteral were, generally, imprecisely translated. Moreover, some verb derivatives are alternatively used to express the same senses.
\end{abstract}

Index Terms - affixes, derivatives, infixated, quadrilateral and triliteral, verb phrase

\section{The VERB Phrase in ARABIC}

The verb phrase ${ }^{1}(\mathrm{VP})$ is basically simple i.e. it consists of one lexical verb (e.g. جاء الؤلد ja?a alwaladu. The boy came).However, verbs of beginning and of to be (e.g, شرع , شعarana) can co-occur with other lexical verbs to form compound VPs ( e.g بأ بقطف ثمار صبره bada?a yaqtifu thimãra şabbrih .He started to obtain the fruits of his patience).(Khalil,1999,p.232-3). The treatments of verbs by traditional and modern Arab grammarians prove that verbs have received a variety of classifications such as weak vs strong, transitive vs intransitive, base vs derivative etc. The latter categorization is of immediate relevance to the present work because it is morpho-semantic in the sense that the affixes attached to verbs give rise to various meanings that are absent in the base verb forms. Al-Nãiila (1988, p.97) states that in attaching the affixes to the base verb forms, two points should be borne in mind; first, when the verb undergoes the change, this will result in altering meaning. This meaning is distinct from that of the base before the attachment of the affixes. Second, affixation ${ }^{3}$ takes place inconsistently i.e. one verb can be affixated with hamza(glottal stop) while another verb cannot. To the best of the researcher's knowledge, no study has yet been conducted to investigate the accuracy of the translations of such senses from Qur'anic ayahs into English.

\section{Classes of Verbs}

As mentioned in (1. Above) verbs were classed from different angles. The presence or absence of vowels led Arab grammarians to draw a distinction between strong and weak verbs where the former consists of consonants only and the latter involves vowels and consonants as well (Nãsir, 1967, P.47).

As in any other language, Arabic exhibits the transitive-intransitive distinction of verbs which is drawn to indicate whether objects follow verbs or not (e.g. وصل زيد, waşala Zayd; Zayd reached vs فتح زيد الباب fataha Zayd albãb; Zayd opened the door).

In dealing with the base-derivative categorization of verbs, Arab morphologists approximately hold a unanimous agreement that the base is of two types: triliteral and quadriliteral. These two subtypes can be affixated (i.e. prefixated, infixated and suffixated) to produce a lot of derivatives. Ibin Jinny (d.392 h,1999:41), among others, (e.g. al-Hamlawy, 1957, P.29, 36; al-fadiithy,2003,P.253 ...), confirms that verbs in Arabic are divided into base and derivatives. The former is called so because its radicals are basic constituents of its building where the omission of one of such radicals results in spoiling the form and meaning of such verbs (e.g. كتبَ.kataba, wrote; سلسل ,salsala, sequenced ${ }^{4}$ ). The attachment of affixes to the base forms leads to the formation of derivatives that are distinct in form and meaning from the triliteral and quadriliteral ${ }^{5}$.

\footnotetext{
${ }^{1}$ The verb phrase is used in the present study in the traditional sense not in the transformational sense.

${ }^{2}$ 2All the Arabic examples, apart from Quranic ayahs, were translated into English by the researcher.

${ }^{3}$ Affixation is an umbrella term used in morphology to refer to prefixation, infixation and suffixation

4 Unlike in English, the base verb forms in Arabic are listed in the perfect forms in Arabic dictionaries.

${ }^{5}$ The triliteral consists of three radicals whereas the quadriliteral is of four radicals as the deletion of any of these radicals makes the verb meaningless.
} 


\section{THE BASE VERB FORMS}

Apart from the diacritics that the morphological patterns can receive, the base verbs have two morphological patterns فَعَ fa'alalala for the triliteral and quadriliteral, respectively. Primarily, the value of these two morphological patterns are twofold:(1) to distinguish which radicals are basic and which are affixes, and (2) to recognize the possible

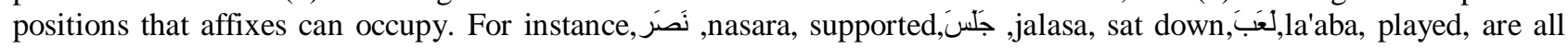
triliterals, but they can be affixated where new meanings are produced(see 1.2.1 below). This holds true of the quadriliterals as well; e.g. بَعََرَ, ba'thara, scattered,حَرَجَ, harjama,gathered etc.(Shlãsh,1972,p.21-47; see also Shlãsh etal, 1989,p.56).

\section{The Derivatives of the Triliteral}

As referred to in (1.1 above), the triliteral can be prefixated, infixated and suffixated to produce the derivatives of the triliteral. The radicals attached to the base are grouped in a meaningless word"سألتمونيها", sa?ltumunyhã. In this regard, Ibin Jinny(d.392 h,2005,p.13)notices that:

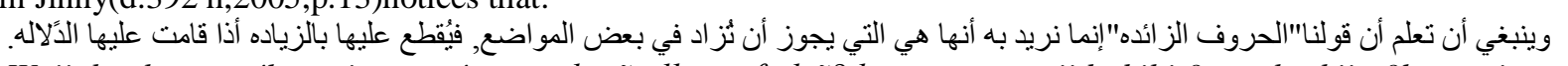

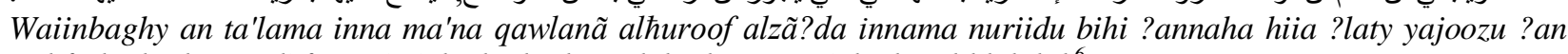
twzãd fii bađi almawã̃đ' fayuqț'u 'alayhã bialzzyãdah idã qãmat 'alayhã alddalãlah ${ }^{6}$

One should recognize that the introduction of affixes is intended here to refer to some possible positions that these affixes can occupy. This can be settled by evidence where the affixated radicals can be omitted, and the base remains able to stand alone with a full sense.

Al-Nãiila (1988,p.98), among others, emphasizes that the triliteral can be affixated with one radical (e.gَرََّسَ, darrasa,

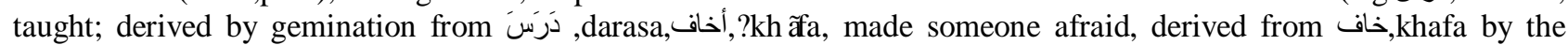

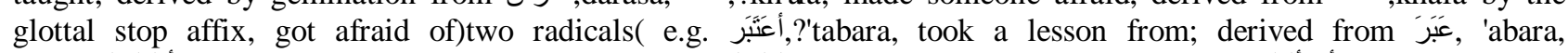

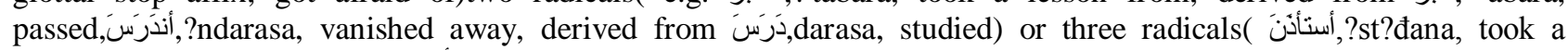

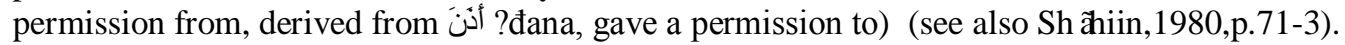

In looking at the above examples, one can easily recognize how far the derivatives are largely different in form and meaning from the trilateral base (for more details see below).

\section{1). The Triliteral affixated with one radical: Its senses}

The triliteral which is affixated with one radical has three morphological patterns: أفعل ?f 'ala, such as أكرم ?krama,

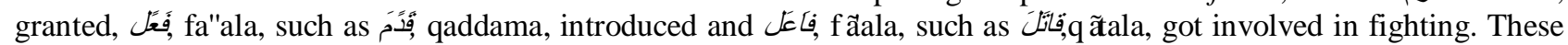
morphological patterns have some senses to exhibit as morphologists differ in introducing such senses to the extent that some say that they (the senses) are ten in number or more. Nevertheless, the most common senses will be discussed here. The affixation of the triliteral with the glottal stop ( I hamza) is basically meant to change the base from intransitivity into transitivity('đaimah ,1955,p.100-101).

$$
\begin{aligned}
& \text { وَقَفَ علي عند الباب.1a } \\
& \text { Waqafa Aliun 'nda albãbii. Ali stopped near the door. } \\
& \text { أوقفتُ عليًا عند الباب.2. }
\end{aligned}
$$

Discussing the morphological structures in Sibbawayh 's book "Al-Kitãb", al-Hadiithy(2003,p.262), as some think so, speaks of the opinion that the glottal stop affixated to the triliteral has many senses; the most common of which are(1)possession,(2)exposure,(3)removal,(4) over-exaggeration and abundance etc. The examples below will be given according to the senses mentioned.

3tmara alrajulu.

The man had dates.

أقتَلَ سائقُ السيارةًَ الرجُلَ بسر عته اللامعقو لها.

?qtala sã?qu alsayãrata alrajula bisir'atihii allama'qulah.

The car driver, due to his unreasonable speed, exposed the man to death.

5. أقَّيتُ عين ولائ aqzayitu 'aynu walady.

I removed dust from my son's eye.

6.

The orchard became greatly full of trees.

(See also Al-Nãiila, 1988, p.99; al-Hamlawy, 1957,P.39-40)

With regard to the morphological pattern $\mathrm{fa}^{\prime}$ ' 'ala, it indicates that the trilateral is made a derivative by geminating the second radical. Sibbawayh ${ }^{7}$ (d.180h.1982, p.63-64), as other morphologists do, (e.g.'đaimah (1955, p.107), holds the thesis that this derivative is used for indicating the high frequency of doing an action repeatedly e.g.

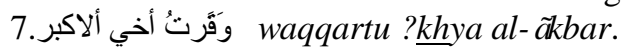

I over-dignified my eldest son many times.

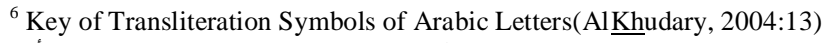

a $\mathrm{a}$ b:ب t:ت th: ث

${ }^{7}$ It is a tradition in Arabic linguistics that the death dates of ancient Arab traditional grammarians are mentioned next to their names because such death dates enable readers (1) to know the school of grammar the scholar belongs to and (2) to familiarize them with the general trends of the school on the scholar's day.
} 
The same morphological pattern can convey the sense of transference from one state to another.

8. عَجُزَتْ زوجتي مبكرا 'ajjazat zawjaty mubakiran.

My wife became old early.

In addition, that intransitive verbs could be changed into transitive ones is possible to carry out by the use of the same morphological pattern.eg

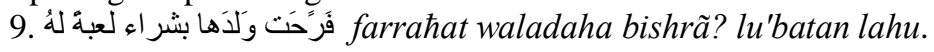

She delighted her son by buying him a toy.

The morphological pattern line, Sibbawayh (d.180h.1982,P.68) speaks of its main sense as follows:

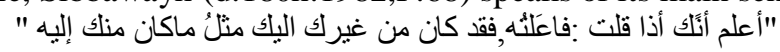

?' 'lam ?nnaka? ?̇ãa qulta fa'altuh, faqad ;kãna min ghayruka ?layka mithlu mã kãna minka ?layh

In uttering the morphological pattern fã'ala, one should recognize that the speaker receives from the other party the same type of activity that the speaker does to the other party.

This signifies that the two parties are involved in doing an action to the same extent that they participate in fulfilling it. e.g.

10. شارك الطلاب في بناء قاعة الدرس shãraka alţilãbu fii binã? Qã' ati ãldaris.

Students took part in building the study room.

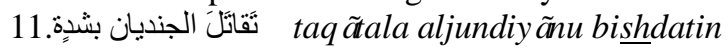

The two soldiers got involved in fighting each other fiercely.

Shlãsh(1971,p.324-6) introduces an exhaustive treatment of the senses of such a derivative in that he lists eighteen senses. However, some of them are farfetched. For instance, he (ibid) says that the sense of having someone fallen into a trap is quite possible to express by such a derivative.

11. غازى سعدِّ غريمِ khãzã Sa 'dun gharymihi.

Saad has his opponent fallen in disgrace.

\section{2). The Triliteral affixated with two radicals: Its senses}

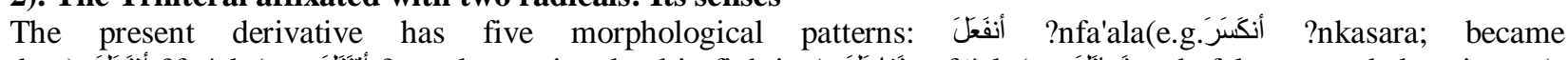

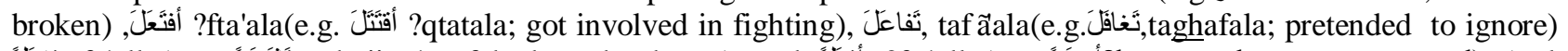

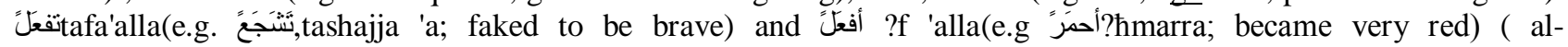
Hadiithy,2003,p.264-267).

In introducing its main senes, Ibin Jinny(d.392 h,1999,p.95-96) proves that the first morphological pattern ?nfa'ala signifies that the verb is always intransitive. The main, if not the only, sense that the derivatives coined on the basis of this pattern is to show that something or someone is influenced by an order or some force.

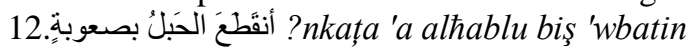

The rope became cut with difficulty.

The above example indicates that someone cut the rope since the rope is unable to cut itself.

Sibbawayh(d.180h.1982,p.74) refers to the point that the morphological pattern 'أفنَّك ?fta'ala has two basic meanings to convey: undertaking and assiduity.

13.

Mohmmed took his friend as a servant. (Undertaking)

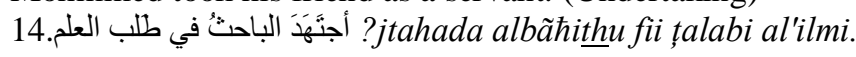

The researcher worked hard to gain knowledge.

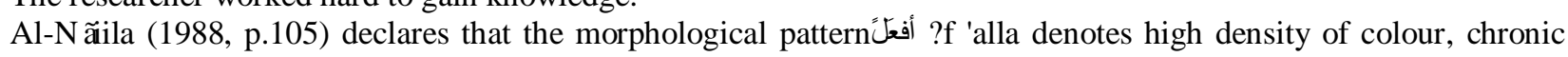
bodily defects and exaggeration .e.g.

15. أحمرً لونُه.

His face- colour turned very red.

16. أسوًَ الليلُ

Night became very deeply dark.(exaggeration)

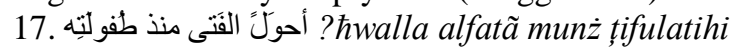

The young boy became cross-eyed since his childhood.

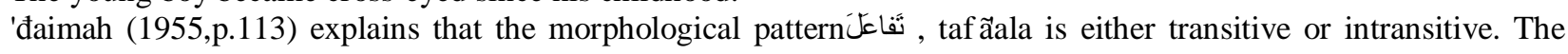
transitive has two main senses: the involvement of the subject and of the object (provided that they are human) in carrying out an action, and to show some sort of pretence.eg

18. نَاقشَ الوزيرُ مع مستشاريه tanãqasha alwaziir ma 'a mustashãryh.

The minister got involved in discussion with his advisers.

19. تَمَارَضَ الطفلُ tamãradha alțiflu

The child pretended to be sick.

Shlãsh etal( 1989,p.96) maintain that the morphological pattern تفعَ' tafa'alla is used for showing the following senses:(a) to oblige oneself to do an action that involves hardship and agony,(b) undertaking, and (c) gradual doing of an action.eg

20. نَصَبرٍ الرجلُ taşabarra alrajulu. 
The man faked to be patient.

21. تَوَسَدً عمرُ يده tawasadda 'Amru yadahu

Amru took his hand as a pillow.

22. تَجَرَعَ الماءَ taja'a"a alma?a

He gradually drank water dose by dose.

Al-Hadiithy (2003, p.266) made a survey of senses of the present derivative as she mentioned that it can express the sense of making sure of something.e.g.

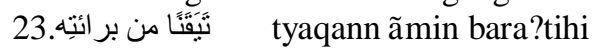

We made sure of his innocence.

\section{3). The Triliteral affixated with three radicals: Its senses}

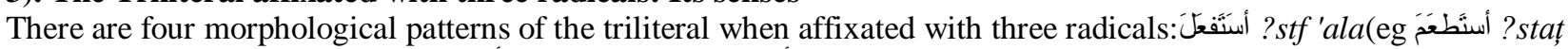

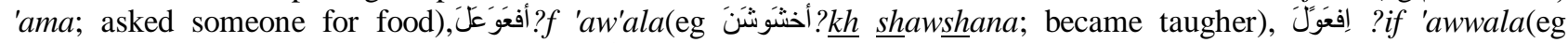

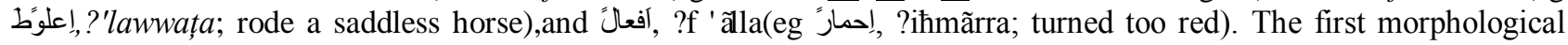
pattern of the present derivative is more recurrent than other patterns. Therefore, it is the only pattern whose senses will be highlighted here.

Sibbawayh (d.180h.1982, p.70-71) holds the view that this derivative is usually basically used for asking something from someone .e.g.

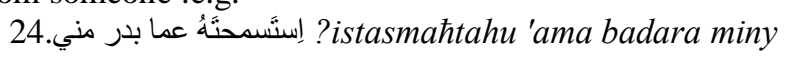

I asked him to forgive me of what I did.

Ibin Jinny(d.392 h,1999,p.100) indicates the fact that such a derivative can be transitive or intransitive.eg

25. لايستأخرون la yast?khirwna ?badan

They did not utterly get late.

Moreover, he (p.101) says that one of its senses is to show change from one state to another.eg

26. أسنَحالَ الثَّجُج ماءُ

Ice turned into water.

'đaimah (1955,p.124) indicates that the morphological pattern in question can express the sense of discovering something or someone in its/his real essence.

27.27akramtahu

I found him generous.

\section{Translations of THE TRILITERAL's DERIVATIVES AS Found IN QURÃNIC AYAHS}

The present section is devoted to the discussion and assessment of the translations of ayahs containing the derivatives introduced above. Instances of Qur'ãnic ayahs will be cited according to the senses of each derivative. The derivatives concerned will be underlined throughout all ayahs quoted, and item-analysis is followed in discussing ayahs linguistically and assessing the renditions one by one.

It is thought that the number of ayahs seems enough to pass judgments over whether the renditions are accurate or not. Alternative translations will be suggested to those ayahs that are inadequately rendered.

To serve this purpose, four published translations of the Qurãn will be consulted, rendered by:

1. Ali, A. Y (1934)

2. Al-Hilali, M. and Khan, M. M. (1996)

3. Pickthall, M. M. (1930)

4. Shaker, M. H. (2003)

The above - mentioned translators' names are, respectively, abbreviated as follows: Ali, Hi. - Kh., Pick. and Sh.

\section{A. Ayahs Containing Triliterals Affixated with One Radical}

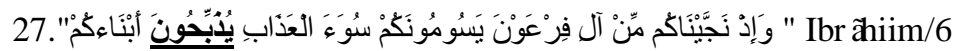

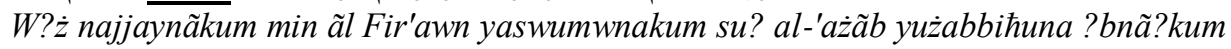

Ali (p.249) He delivered you from the people of Pharaoh: they set you hard tasks and punishments, slaughtered your sons.

Hi. - Kh(p.328) He delivered you from Fir'aun(Pharaoh) people who were afflicting you with horrible torment, and were slaughtering your sons.

Pick.(p.256)He delivered you from Pharaoh's folk who were afflicting you with dreadful torment, and were slaying your sons.

Sh.(p.306) He delivered you from Firon's people, who subjected you to severe torment and slew your sons.

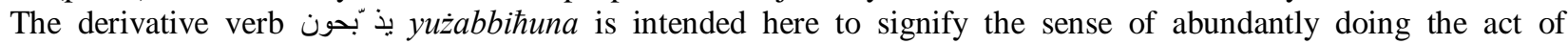
slaughtering Jews' sons by Pharaoh's supporters. All the renditions above failed to convey the sense concerned. It is thought that the appropriate translation of this ayah is: He delivered you from Pharaoh's people who were afflicting you with horrible torment, and were abundantly slaughtering your sons.

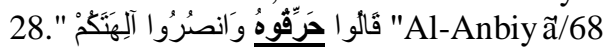

Qãlw harriquhu w? nşirw ãlihatukum 
Ali (p.322) They said," Burn him and protect your gods"

Hi. - Kh(p.435) They said:" Burn him and help your ãliha(gods)"

Pick.(p.327) They cried: Burn and stand by your gods.

Sh.(p.386) They said: Burn him and help your gods.

All the translations were inaccurate to covey the exact sense of the geminated triliteral derivative due the fact that the derivative is rendered "burn" where there is no indication to the sense of overdoing the act of burning. The ayah should be rendered as: They said" over-burn him and stand by your gods".

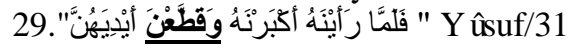

Falmma ra?ynahu waqțta'na ?ydiyahunna

Ali (p.232)" When they saw him, they did extol him, and (in their amazement) cut their hands.

Hi. - Kh.(p.306) Then, when they saw him, they exalted him(at his beauty) and( in their astonishment) cut their hands.

Pick. (p.239)And when they saw him, they exalted him and cut their hands.

Sh. (p.288) So, when they saw him, they deemed him great, and cut their hands.

These three ayahs contain a derivative (قَّ $)$ of the trilateral by means of gemination to reflect the sense of carrying out the act of cutting women's hands many times. Accordingly, the alternative translation is: Then, when they saw him, they exalted him (due to his handsomeness) and cut their hands many times.

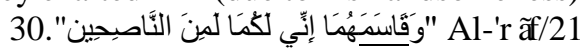

Waqãsamahumã ?nny lakumã min al-nnaşihyn

Ali (p.153) And he swore to them both that he was their sincere adviser.

Hi. - Kh.(p.202)And he[Shaitãn(Satan)] swore by Allãh to them both(saying):"Verily, I am one of the sincere wellwishers for you both.

Pick.(p.152) And he swore unto them(saying):Lo! I am a sincere adviser unto them.

Sh.(p.198) And he swore to them both: Most surely I am a sincere adviser to you.

The derivative in the above Qur'ãnic ayah"قاسََ" is to signify the sense of participation in fulfilling an action. This means that Satan swore to Adam and Eve of his sincere advice; and they, in turn, did their best to make sure of his credibility. Due to their purity and innocence, Adam and Eve trusted the Satan as both expected that no creature, at their time, could dare to swear untruthfully (Mughnyyah, 1995:157). Therefore, both parties were involved in this action. As for the renditions, it seems that Hi. - Kh.'s translation is more accurate than others' in expressing the sense intended.

\section{2."As-Sãffãt/25 \\ Mãlakum lãtanaşaruwn}

Ali (p.438)"What is the matter with you that ye help not each other?"

Hi. - Kh.(p.600) What is the matter with you? Why do you not help each other?"

Pick.(p.447) What aileth you that ye help not one another?

Sh.(P.515) What is the matter with you that you do not help each other.

Concerning the translations of the above ayah, all are accurate to convey the precise sense of it including the meaning of the derivative involved. This is due to the introduction of the pronoun "one another or each other" with the verb help. Semantically, this signals the sense of involvement in doing the act.

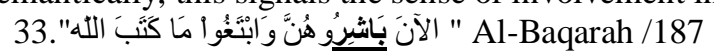

?lãna bãshruhinna wa?btaghw mãkataba Allãh

Ali (p.30) so now associate with them, and seek what Allah hath ordained.

Hi. - Kh.(p.38)So now have sexual relations with them and seek that which Allãh has ordained for you.

Pick.(p.29)So hold intercourse with them and seek that which Allãh hath ordained for you.

Sh.(P.60) So now be in contact with them and seek what Allah has ordained for you.

All renditions above are imprecise owing to the absence of any lexical or grammatical indication that shows the sense of participation signified by the underlined derivative. Therefore, the following translation is thought more appropriate: So now get involved in sexual relations with them and seek what Allãh has ordained for you.

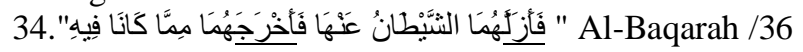

Fa?zalahumã al-shshayțãnu 'anhã fa? khrajahumã mimmã kãnã fyhi

Ali (p.6) Then did Satan make slip from the (Garden), and get them out of the state (of felicity) in which they had been.

Hi. - Kh.(p.9) Then the Shaitãn(Satan) made them slip therefrom (Paradise), and got them out from that in which they were.

Pick.(p.6)But Satan caused them to deflect therefrom and expelled them from the (happy) state in which they were.

Sh.(p.36) But the Shaitan made them both fall from it, and caused them to depart from that(state) in which they were.

The above ayah contains two derivatives which are underlined and they are transitive expressing the sense of removal (see1.2.1.1. above).Put differently, it means that the Satan removed the state of happiness from Adam and Eve and made them lose it.With regard to its renditions, the ayah is accurately translated by Ali since his lexical choices are more precise than others' in conveying the meaning concerned.

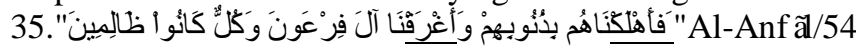




\section{Fa?hlaknãhum biżunwbihim wa?ghraq ?la Fir'aun wakullun kãnw đãlimyn}

Ali(p.182)so We destroyed them for their crimes, and We drowned the people of Pharaoh: for they were all oppressors and wrong-doers.

Hi. - Kh.(p. 239) so We destroyed them for their sins, and We drowned the people of Fir'aun(Pharaoh) for they were all Zãlimũn(polytheists and wrong-doers).

Pick.(p.184) so We destroyed them in their sins. And We drowned the folk of Pharaoh. All were evil-doers.

Sh.(p.233) therefore We destroyed them on the account of their faults and We drowned Firon's people, and they were all unjust.

The above ayah contains two derivatives which are underlined and they are transitive expressing the sense of exposure in that Pharaoh's followers were exposed to destruction and drowning due to their wrong deeds. The translation of the ayah by Hi. - Kh. is adequate enough to reflect the sense of the ayah including the two derivatives concerned.

\section{B. Ayahs Containing Triliterals Affixated with Two Radicals}

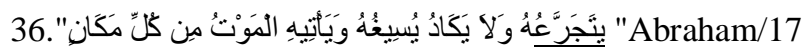

Yatajarra'ahu walayakadu yastasyghahu way?tyhi almawtu min kulli makãn.

Ali(p.250) In gulps will he sip it, but never will he be near swallowing it down to his throat: death will come to him from every quarter.

Hi. - Kh.(p. 330) He will slip it unwillingly, and he will find a great difficulty to swallow it down his throat and death will come to him from every side.

Pick. (p.257) Which he sippeth but can hardly sallow, and death cometh unto him from every side.

Sh.(p.308)He will drink it little by little and will not be able to swallow it agreeably, and death will come to him from every quarter.

The above Qurãnic ayah contains the derivative"تَجَرَُّعَ; tajarra'a: drank little by little with much difficulty" of whose senses is to show gradual doing of an action that involves hardship and agony. Sh.'s rendering is the most adequate one because it reveals how difficult and hard the act of drinking water little by little unwillingly.

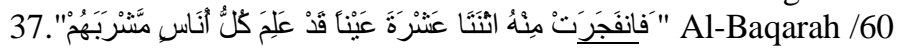

Fa?nfajarat minhu ?thnata 'asharata 'aynan qad 'alim kullu ?unãsin mmashrabuhim

38." Al-shams/12

?z ?nba'atha ?shqũha

Ali (p.594) Behold, the wicked man among them deputed (for impiety).

Hi. - Kh.(p. 842) When the most wicked man among them went forth( to kill the she-camel).

Pick. (p.595)When the basest of them broke forth.

Sh.(694) when the most unfortunate of them broke forth with.

The derivative (أنبَحَثَ)?nba'atha)found in the above ayah is intended to express the sense of over-exaggeration in doing an act as the doer is motivated by some force or an order. The context of the ayah indicates that the most obstinate disbeliever (who saw tangible evidence i.e. the she-camel) of the people of the prophet, Salih, was motivated by his distrust of the prophet's message. The translations of the ayah were inaccurate due to the absence of lexically adequate equivalents to express the senses found in the original. As such, the ayah should be translated as follows: When the most wretched man among them went forth (to kill the she-camel).

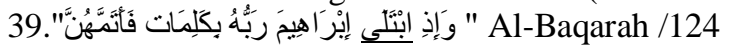

wa? $\dot{z}$ ?btalã ?Brahyma rabbuhu bikalimãtin

Ali(p.19)And remember that Abraham was tried by his Lord with certain commands, which he fulfilled.

Hi. - Kh. (p. 23) And remember when the Lord of Ibrãhîm(Abraham) (i.e,Allãh) tried him with (certain) commands, which he fulfilled.

Pick. (p.19)And (remember) when his Lord tried Abraham with (His) commands, and he fulfilled them.

Sh.(p.50) And when his Lord tried Ibrahim with certain words, he fulfilled.

The derivative ابتَّى ?btalã: tried expresses the sense of undertaking (see1.2.1.2. above)i.e. the responsibility of fulfilling the Lord's commands. Regarding the renditions, it seems that Ali's translation is sounder to convey the senses present in the source text. This is attributed to the use of passive construction that shows the thematic focus intended.

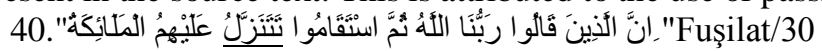

?nna all-żyna qãlw rabbunã Allãhu thumma ?staqãmu tatanazzalu 'alayhum al-mala?kat

Ali (p.471) In the case of those who say, "Our Lord is Allah", and further,

stand straight and steadfast, the angels descend on them( from time to time).

Hi. - Kh. (p. 648) Verily, those who say;"Our Lord is Allãh (Alone),"and then they stand firm, on them angels will descend (at the time of their death).

Pick. (p.480)Lo! Those who say: Our Lord is Allah, and afterward are upright, the angels descend upon them.

Sh.(p.552) As for those who say: Our Lord is Allah, then continue in the right way, the angels descend upon them.

The derivative in the above ayah is meant to show the gradual doing of an action. This is clearly seen in that the ayah indicates that angels' descending on the straight and steadfast people is from time to time. Ali's translation is more correct in referring to the gradual descending of angels on those believers (according to the Islamic commentaries). 


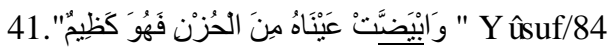

Wa?byadhdhat 'aynãhu mina alhuzni fahuwa kadhym

Ali (p.239) And his eyes became white with sorrow, he was suppressed with silent sorrow.

Hi. - Kh. (p. 314) And he lost his sight because of the sorrow that he was suppressing.

Pick. (p.245)And his eyes were whitened with the sorrow that he was suppressing.

Sh.(p.295) and his eyes became white on the account of the grief, and he was a suppressor( of the grief).

One of the senses of the derivative found in the Qur'ãnic ayah is to signify high density of colour and chronic bodily defects. The translations above lack the lexical item that indicates such a sense. Accordingly, the alternative translation is: and his eyes became highly whitened because of his grief that he was a suppressor of.

C. Ayahs Containing Triliterals Affixated with Three Radicals

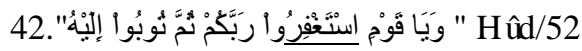

Wayaqawm ?staghfiru rabbakum thuma twbu ?layhi

Ali (p.221)" And O my people! Ask forgiveness of your Lord, and turn to Him (in repentance).

Hi. - Kh. (p. 293)"And O my people! Ask forgiveness of your Lord and then repent to Him.

Pick. (p.227) And, O my people! Ask forgiveness of your Lord, then turn unto Him repentant.

Sh.(p.276) And, O my people! ask forgiveness of your Lord, then turn to Him.

Of the uses of this derivative is usually basically to ask something from someone. This holds true of example (43) . Three renderings of the ayah have remained imprecise due to either the absence of appropriate equivalents or the mischoice of structures. However, Hi. - Kh.'s translation is accurate in expressing the meaning of the ayah as a whole.

43."Al-Fatiћah/5

?yyãka na'budu wa?yyãka nasta'yn

Ali(p.1)Thee do we worship, and Thine aid we seek.

Hi. - Kh. (p.1) You (Alone) we worship, and You (Alone) we ask for help (for each and everything).

Pick. (p.1)Thee (alone) we worship;Thee(alone) we ask for help.

Sh.(p.31)Thee do we serve and thee do we beseech for help.

Hi. - Kh.'s rendering is appropriate to highlight the sense of asking that the derivative exhibits.

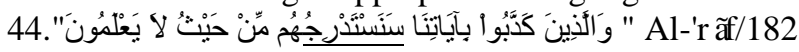

Wallażyna każżabw bi?yãtina sanastadrijuhum mmin ћaythu la'lamwn.

Ali(p.173) Those who reject Our signs, We will lead them step by step to ruin while they know not.

Hi. - Kh. (p. 227) Those who reject Our Ayãt(proof, evidences,verses, lessons, signs, revelations etc.), We shall gradually seize them with punishment in ways they perceive not.

Pick. (p.174)Those who deny Our revelations-step by step We lead them on from whence they know not.

Sh.(p.222) And(as to) those who reject our communications, we draw them near(destruction) by degrees from whence they know not.

The derivative in this ayah is used for showing gradual change from one state to another (see 1.2.1.3. above).This sense is not rendered accurately. It should have been translated as: As for those who did not believe Our revelations, We shall gradually lead them step by step from welfare to misery as they know not.

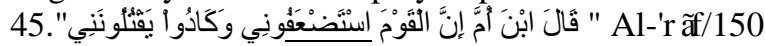

Qãla ?bin umm ?nna al-qawm? ?tadh'afuny wakadu yaqtilwnany

Ali(p.169)To him Aaron said:"Son of my mother! The people did indeed reckon me as haughty, and went near slaying me!

Hi. - Kh. (p. 221) Aaron said:"O Son of my mother! Indeed the people judged me weak and were about to kill me.

Pick. (p.169)He said: Son of my mother! Lo! The folk did judge me weak and almost killed me.

Sh.(p.217) He said: Son of my mother! Surely the people reckoned me weak and had well-nigh slain me.

The verb derivative of this morphological pattern can express the sense of discovering something or someone in its/his real essence. This is what the verb derivative signifies here in that Moses' people found his brother Aaron weak when Moses went to receive the tablets of (al-Torah) the Old Testament from his Lord. It is Hi. - Kh.'s translation shows accuracy in conveying the sense of the ayah.

\section{CONCLUSIONS}

The theoretical discussion of the triliteral verb derivatives and assessment of the translations of the ayahs containing such derivatives have yielded some findings. First of all, Arab morphologists hold a high degree of unanimity as far as the senses that verb-derivatives express. It is possible for more than one morphological patterns (on the basis of which such derivatives are coined) to be used in conveying the same sense. Moreover, some derivatives are very rare to encounter in Qurãnic surahs.

As for translation assessment, generally, the translations of the ayahs containing the triliteral verb derivatives have been inadequate either due to the absence of appropriate grammatical structures or sound lexical choices. This is attributable to the fact that Qurãnic texts are pregnant with meanings to the extent that overtranslation becomes inescapable for translators to resort to in filling the syntactic and lexical gaps between both languages. In addition, some 
verbs which are turned into derivatives by germination were not accurately rendered owing to the fact that germination in Arabic is functional but it is not so in English. However, this does not mean that such verbs are untranslatable. Finally, a separate study is worth conducting to investigate the translation accuracy of the quadriliteral derivatives in Qurãnic surahs.

\section{REFERENCES}

[1] Ali, A. Y (1934). The Holy Qur'an.Beirut Dar Al-Furqan.

[2] 'đaimah, M. A.(1955). Al-Mughny fi Taşryf Al-Af 'ãl.(The Thorough Treatment of Verbs Morphology).Cairo:Al-'ahd AlJadiid Printing House.

[3] Al-Hadiithy, Kh. (2003). Abniyat Al-ŞŞarif fi Kitãb Sibbawayh. (Morphological Structures in Sibbawayh's Al- Kitãb).Beirut: Lubnan Nashirwn Library.

[4] Al-Hamlawy,A. (1957). Kitãb Shażã Al-'rif fi fan Al-ŞŞarif. (The Art of Morphology).Cairo: Mustafa al-ћalaby Publishing House.

[5] Al-Hilali, M. and Khan, M. M. (1996). Translation of the Meanings of the Nobel Qur'ãn in the English Language. Madinah: King Fahd Complex.

[6] Ibin Jinny (d.392 h,1999). Al-Munşif Sharh Likitãb Al-TaŞryf. By Abi Uthman Al-Mãziny (d.247h).(The Fair Treatment of Morphology). Beirut: Dar Al-kitub Al-'ilmyah.

[7] Ibin Jinny. (d.392 h,2005). Al-TaŞryf Al-Miluky.(Royal Morphology). Beirut: Culture Book Foundation.

[8] Khalil, M. A.(1999). A Contrastive Grammar of English and Arabic. Amman: Jordan Book Center.

[9] Alkhudary, R.(2004). A Dictionary of Islamic Terms. Damascus: Dar Al-Yamamah.

[10] Mughnyyah, M.J. (1995). Al-TtafsyrAl-Mubyn (Explicit Commentary). Beirut: Azaldyn Foundation for Printing and Distribution.

[11] Al-Nãiila, A.A. (1988). Al-ŞŞarif Al-WaŻiћ.(Explicit Morphology). Mousl: Mousl University Press.

[12] NãŞir, R.(1967). The Structure of Arabic: From Sound to Sentence. Beirut: Librairie De Liban.

[13] Pickthall, M. M. (1996.) The Glorious Qur'ãn. Istanbul. Ĉăgri Publications.

[14] Shãhiin, A. (1980). Al-Manhaj Al-ŞŞawty Libunyat Al-'arabyiah: Ru?yah Jadiidah fi Al-ŞŞarif Al-'araby.(The Phonological Treatment of Arabic Morphological Building: (A New Perspective in Arabic Morphology). Beirut: Al-Risãlah Printing House for Distribution.

[15] Shaker, M. H. (2003). Holy Qur'an.Qum: Ansariyan Publications.

[16] Shlãsh, H. T. (1972). Awzan Al-Fi'il Wama'anyha. (Verb Morphological Paradigms and their Meanings). Al-Najaf: Arts Printing House.

[17] Shlãsh H. T.Al-Farţusy, S. M. and Hussein,U. A. (1989). Al-Muhażżab fi'ilm Al-TaŞryf. (An Introductory Survey of the Science of Morphology).Baghdad: Beit Al-hikma Publications.

[18] Sibbawayh, A.U. (d.180h.1982). Al- Kitãb. (The Book) Vol. IV. Cairo: Al-Khanachy Publishing House.

Mehdi F. al-Ghazalli is a PhD holder in linguistics and translation. He worked in Libya, Jordan and Iraq. He has been chairman of Translation Department/Al-Mustansiriyia University since 2009. He has published some papers in local and international refereed journals. His research interests are: contrastive linguistics, translation theory and universal grammar. Dr. al-Ghazalli has been chairman of some examining committees and an external examiner of more than ten M.A theses in translation in Baghdad University and Al-Mustansiriyia University. He has assessed a lot of papers for promotion and for publication. 